\title{
AN EPIDEMIO-CLINICAL AND HISTO-PATHOLOGICAL STUDY OF LICHEN PLANUS
}

\author{
Sanjeev Gupta ${ }^{1}$, H. V. Talanikar², Shruti Ghadgepatil ${ }^{3}$ \\ ${ }^{1}$ Associate Professor, Department of Dermatology, Dr. D. Y. Patil Medical College, Pune. \\ ${ }^{2}$ Professor, Department of Dermatology, Dr. D. Y. Patil Medical College, Pune. \\ ${ }^{3}$ Assistant Professor, Department of Dermatology, Dr. D. Y. Patil Medical College, Pune.
}

\begin{tabular}{l}
\hline ABSTRACT \\
BACKGROUND \\
Lichen planus, a unique cutaneous entity, consists of distinct gross-colour, configuration, pattern, location, appearance - as well as \\
microscopic features. \\
The aim of this study was to assess of epidemiological, clinical and histopathological correlation of lichen planus.
\end{tabular}

\section{MATERIALS AND METHODS}

The study included 50 consecutive patients of Lichen planus presenting to the outpatient department of our institution with involvement of skin and/or mucous membrane irrespective of their age, sex, education, occupation, socio-economic status, duration of illness and associated diseases. In all the selected cases a detailed history according to the proforma was noted. Biopsy was done after taking patient's consent. Findings were tabulated and percentages were calculated.

\section{RESULTS}

In our study popular $(38 \%, 19)$, hypertrophic $(16 \%, 8)$, guttate $(14 \%, 7)$ and linear $(8 \%, 4)$ were the four commonest types of lichen planus. Second decade (32\%) was the most common age group affected. Male-to-female ratio was 1.3:1. Labourer's (34\%, 17), housewives $(30 \%, 15)$ and students $(12 \%, 6)$ formed the majority of our study patients. Maximum $(42 \%, 21)$ patients presented within 3 months of appearance of lesions (range 7 days - 7 years) followed by 22\% presenting within 4 - 6 months and $20 \%$ in 7 - 12 months. Itching which caused discomfort in daily activities was the presenting complaint in $40 \%$ of patients followed by severe itching, which disturbed the sleep along with discomfort in daily activities in $30 \%$ of study patients.

\section{CONCLUSION}

Fifty percent patients belonged to the age group of 21 - 40 years. One case of hypertrophic variety was associated with varicosity. Buccal mucosa and lips were the commonest sites affected in oral lichen planus. Out of 10 patients with oral lesions, 7 had habit of tobacco chewing. Koebner phenomenon was seen in $68 \%$ of cases. Nails were affected in (15) $30 \%$ cases, longitudinal ridging being the commonest manifestation.

\section{KEYWORDS}

Lichen Planus, Papular, Hypertrophic, Guttate, Linear.

HOW TO CITE THIS ARTICLE: Gupta S, Talanikar HV, Ghadgepatil S. An epidemio-clinical and histo-pathological study of lichen planus. J. Evolution Med. Dent. Sci. 2016;5(89):6645-6650, DOI: 10.14260/Jemds/2016/1503

\begin{abstract}
BACKGROUND
Lichen Planus (LP) is a unique cutaneous entity consisting of papules distinct in gross-colour, configuration, pattern, location, appearance as well as microscopic features. It is usually a self-limited condition that most commonly affects middle-aged adults. It can involve glabrous skin, mucous membranes, hair and nails. ${ }^{1}$ The duration of LP is related to the extent and site of involvement. There are recurrences in $12 \%$ to $20 \%$ of patients, more often in those who had generalised cutaneous involvement.
\end{abstract}

\section{MATERIALS AND METHODS}

The study consisted of 50 consecutive cases of clinically diagnosed lichen planus attending the Outpatient Department

Financial or Other, Competing Interest: None.

Submission 30-09-2016, Peer Review 26-10-2016,

Acceptance 02-11-2016, Published 07-11-2016.

Corresponding Author:

Dr. Sanjeev Gupta,

C3 701, Swapna Nagari Society,

Pimpri, Pune.

E-mail: drsanjeevgupta7379@gmail.com

DOI: $10.14260 /$ jemds $/ 2016 / 1503$ of Dermatology, in our tertiary care hospital. The study included patients with lichen planus involving the skin and/or mucous membranes irrespective of their age, sex, education, occupation, socio-economic status, duration of illness and associated diseases. A detailed history was taken in all the selected cases, which included the following :- occupational history, duration of illness, onset of the disease (whether sudden or insidious), progression of the disease associated with itching or burning sensation in the oral cavity, emotional factors if any, habits like tobacco chewing, betel nut chewing and alcoholism, ingestion of any drugs, aggravation of itching on exposure to sunlight, development of new lesions at the site of trauma, associated infections or any systemic illness and any similar illness in the past. A detailed general examination was carried out in all these patients with special importance to oral cavity, genitalia, nails and hair. Skin examination was done in detail with special reference to the predilected sites. All these patients were looked for any systemic disease association. Biopsy was done wherever possible after taking an informed consent from the patients.

\section{RESULTS}

Among our study patients, $32 \%$ belonged to the age group of 21 - 30 years followed by $20 \%$ in 31 - 40 years of age group; 
Half (52\%) of the total cases of the patients belonged to the age group of 21 - 40 years. Youngest patient being 9-year-old and the oldest 75 years.

\begin{tabular}{|c|c|c|}
\hline Age in Years & No. of Patients & Percentage \\
\hline Below 10 years & 1 & $2 \%$ \\
\hline 11 to 20 years & 9 & $18 \%$ \\
\hline 21 to 30 years & 16 & $32 \%$ \\
\hline 31 to 40 years & 10 & $20 \%$ \\
\hline 41 to 50 years & 7 & $14 \%$ \\
\hline Above 50 years & 7 & $14 \%$ \\
\hline Total & $\mathbf{5 0}$ & $\mathbf{1 0 0} \%$ \\
\hline \multicolumn{3}{|c|}{ Table 1 } \\
\hline
\end{tabular}

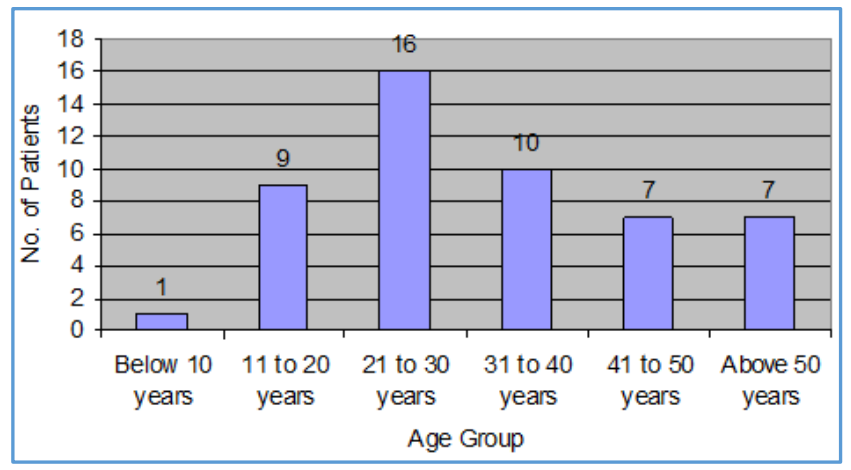

Figure 1

Male-to-female ratio was 1.3:1.

\begin{tabular}{|c|c|c|}
\hline Sex & No. of Patients & Percentage \\
\hline Male & 21 & $42 \%$ \\
\hline Female & 29 & $58 \%$ \\
\hline Total & $\mathbf{5 0}$ & $\mathbf{1 0 0 \%}$ \\
\hline \multicolumn{3}{|c|}{ Table 2 } \\
\hline
\end{tabular}

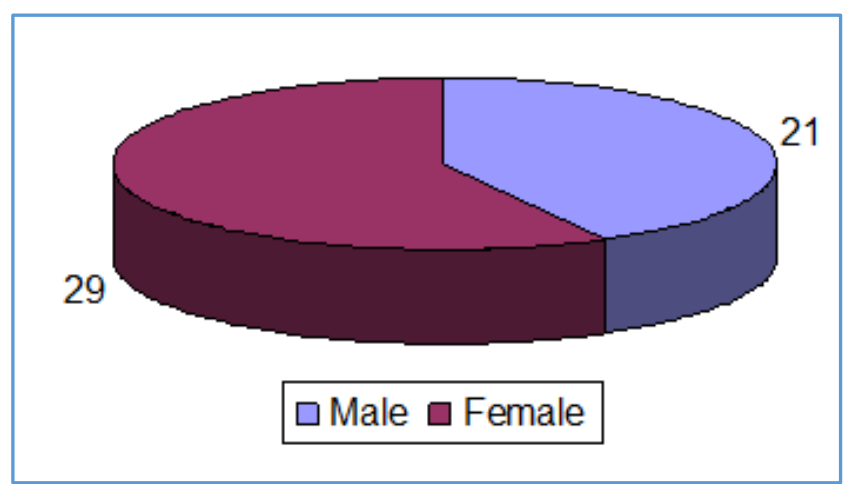

Figure 2

Labourers were the commonest $(17,34 \%)$ occupation in our study population followed by housewives $(15,30 \%)$. Students, professionals, agriculturists and others constituted $36 \%$.

\begin{tabular}{|c|c|c|}
\hline Category & No. of Patients & Percentage \\
\hline Housewives & 15 & $30 \%$ \\
\hline Labourers & 17 & $34 \%$ \\
\hline Students & 6 & $12 \%$ \\
\hline Business & 4 & $8 \%$ \\
\hline Agriculturists & 3 & $6 \%$ \\
\hline Others & 5 & $10 \%$ \\
\hline Total & $\mathbf{5 0}$ & $\mathbf{1 0 0 \%}$ \\
\hline \multicolumn{3}{|c|}{ Table 3 } \\
\hline
\end{tabular}

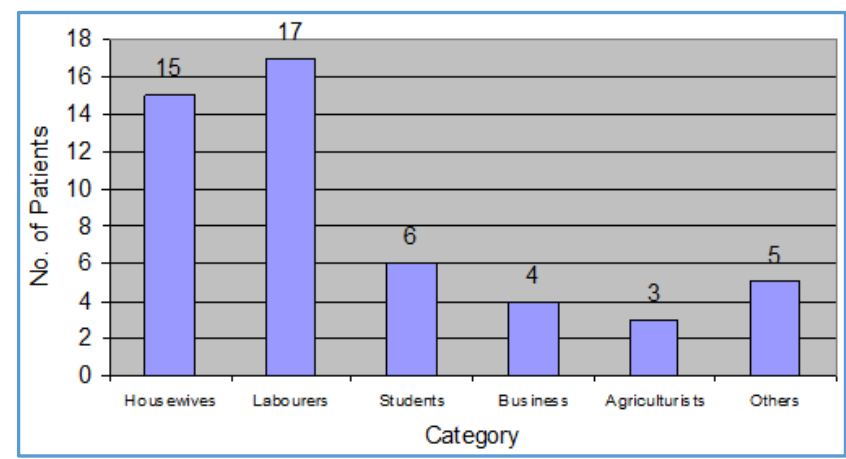

Figure 3

The majority of the patients presented within 3 months (21; 42\%), 4 - 6 months in 11 patients (22\%), 7 - 12 months in $10(20 \%)$ and more than 1 year in 8 patients (16\%). The shortest duration was 7 days and longest was of 6 years. Severe itching was the reason for early presentation in many patients.

\begin{tabular}{|c|c|c|}
\hline Category & No. of Patients & Percentage \\
\hline Up to 3 months & 21 & $42 \%$ \\
\hline 4 - 6 months & 11 & $22 \%$ \\
\hline 7 - 12 months & 10 & $20 \%$ \\
\hline More than 1 year & 8 & $16 \%$ \\
\hline Total & $\mathbf{5 0}$ & $\mathbf{1 0 0} \%$ \\
\hline \multicolumn{3}{|c|}{ Table 4 } \\
\hline
\end{tabular}

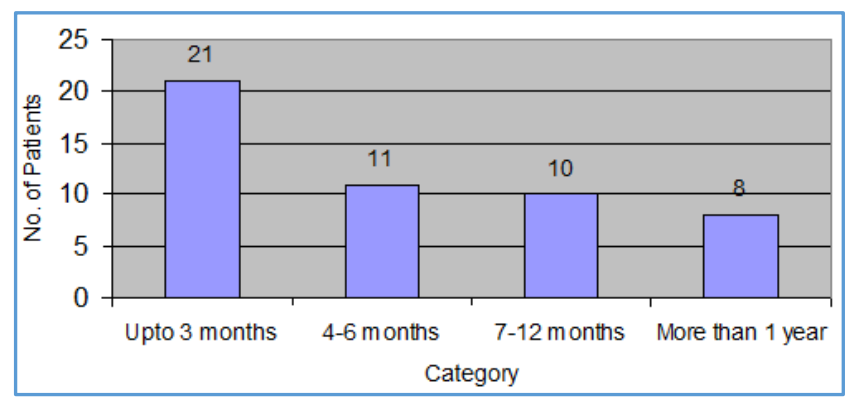

Figure 4

In the present study, $40 \%$ of patients had moderate itching which caused discomfort in their daily activities followed by severe itching in 30\%, which hampered their daily activities as well as sleep; $10 \%$ of the patients were asymptomatic.

\begin{tabular}{|c|c|c|}
\hline Category & No. of Patients & Percentage \\
\hline Asymptomatic & 5 & $10 \%$ \\
\hline Mild itching & 10 & $20 \%$ \\
\hline Moderate itching & 20 & $40 \%$ \\
\hline Severe itching & 15 & $30 \%$ \\
\hline Total & $\mathbf{5 0}$ & $\mathbf{1 0 0 \%}$ \\
\hline \multicolumn{3}{|c|}{ Table 5 } \\
\hline
\end{tabular}

[Mild itching - Itching does not hamper the daily activities, Moderate itching - Hampers the daily activities, Severe itching - Hampers the daily activities and disturbs the sleep]. 


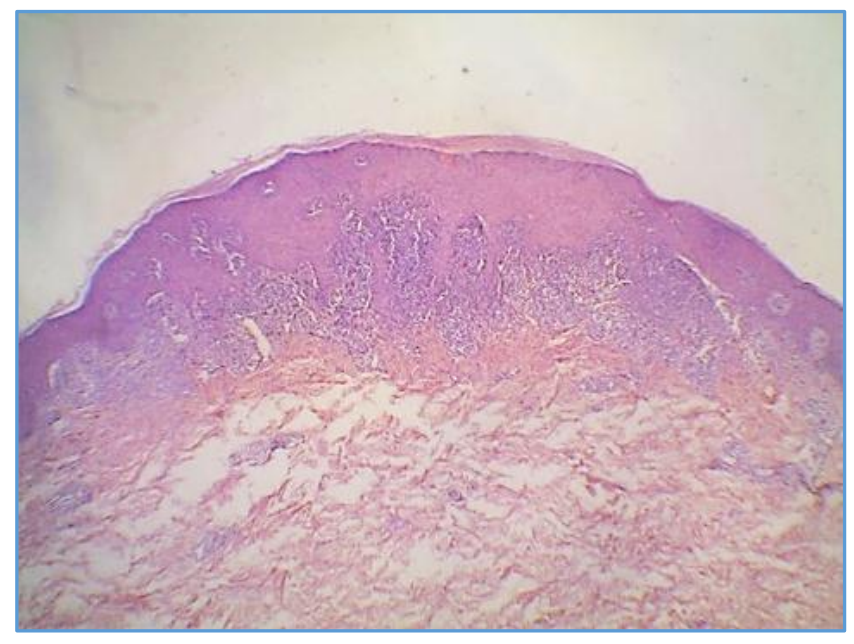

Figure 5

In the present study, 10 patients had a habit of smoking/chewing tobacco or drinking alcohol. Among males 4, 2 and 1 patients were tobacco/betel nut chewer, smokers and alcoholic respectively. All the 3 females had the habit of tobacco/betel nut chewing. Out of 10 ten cases of oral lichen planus, 7 patients had the addiction of tobacco chewing.

\begin{tabular}{|c|c|c|c|}
\hline Sex & $\begin{array}{c}\text { Tobacco/Betel Nut } \\
\text { Chewer }\end{array}$ & Smokers & Alcoholic \\
\hline Males & 4 & 2 & 1 \\
\hline Females & 3 & - & - \\
\hline Total & 7 & 2 & 1 \\
\hline \multicolumn{3}{|c|}{ Table 6 } \\
\hline
\end{tabular}

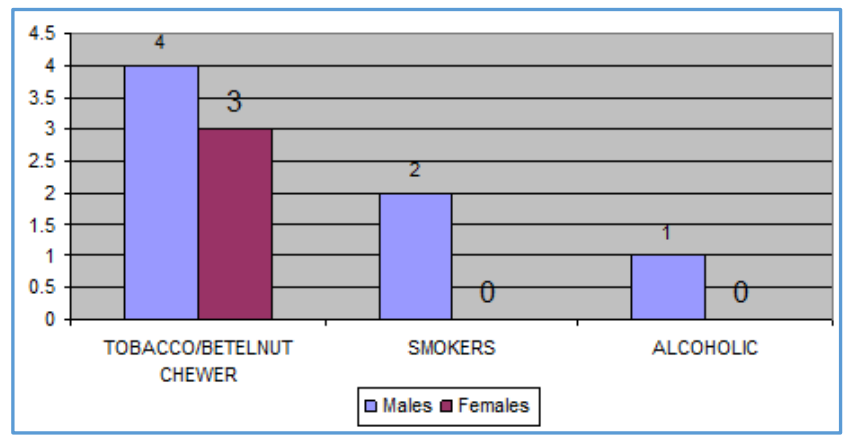

Figure 6

In the present study, the commonest $(19,38 \%)$ type of lichen planus clinically was papular variety followed by hypertrophic $(8,16 \%)$ and guttate $(7,14 \%)$ variety.

\begin{tabular}{|c|c|c|}
\hline Types & No. of Cases & Percentage \\
\hline Papular & $\mathbf{1 9}$ & $\mathbf{3 8 \%}$ \\
\hline Guttate & 7 & $14 \%$ \\
\hline Hypertrophic & 8 & $16 \%$ \\
\hline Linear & 4 & $8 \%$ \\
\hline Actinic & 3 & $6 \%$ \\
\hline Annular & 3 & $6 \%$ \\
\hline Follicular & 2 & $4 \%$ \\
\hline Pigmented & 1 & $2 \%$ \\
\hline Atrophic & 1 & $2 \%$ \\
\hline Zosteriform & 1 & $2 \%$ \\
\hline Oral & 1 & $2 \%$ \\
\hline Total & $\mathbf{5 0}$ & $\mathbf{1 0 0 \%}$ \\
\hline \multicolumn{3}{|c|}{} \\
\hline
\end{tabular}

In the present study only cutaneous involvement was seen in $80 \%$ of patients, both skin and mucous membrane involvement was seen in $18 \%$, whereas a single patient presented with only oral lesions.

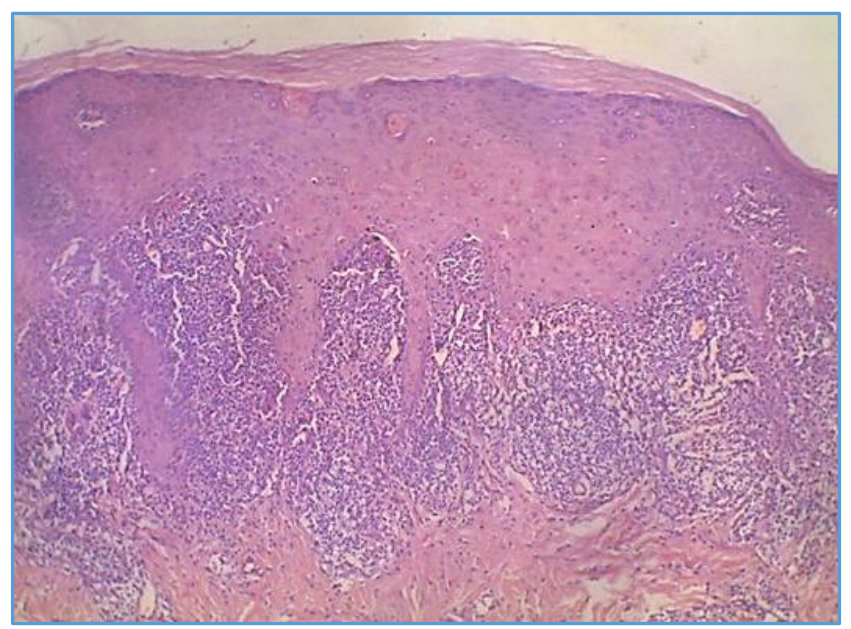

Figure 7

\begin{tabular}{|c|c|c|}
\hline Site & No. of Cases & Percentage \\
\hline Scalp & 1 & $2 \%$ \\
\hline Face \& neck & 10 & $20 \%$ \\
\hline Trunk & 27 & $54 \%$ \\
\hline Upper limbs & 36 & $72 \%$ \\
\hline Lower limbs & 38 & $76 \%$ \\
\hline Palms \& soles & 4 & $8 \%$ \\
\hline Genitalia & 7 & $14 \%$ \\
\hline Generalised & 7 & $14 \%$ \\
\hline Oral lesions & 10 & $20 \%$ \\
\hline \multicolumn{3}{|c|}{ Table 8} \\
\hline
\end{tabular}

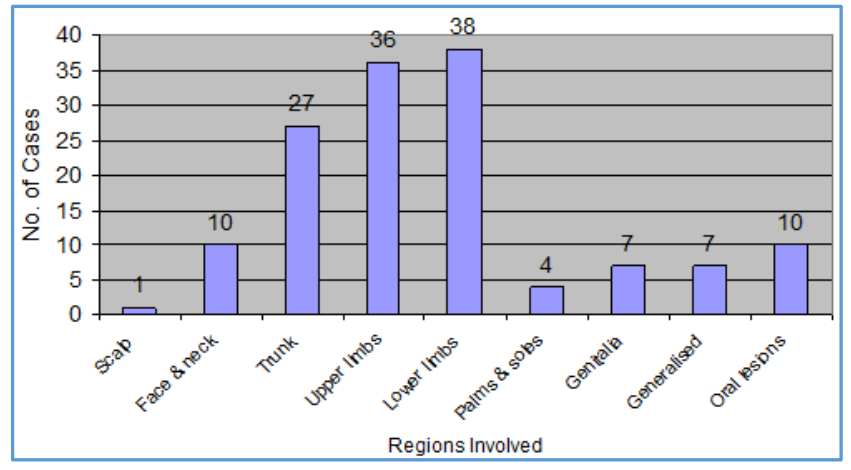

Figure 8

In the present study, lower $(38,76 \%)$ and upper limbs (36, $72 \%$ ) were commonly affected followed by the trunk in $54 \%$ (27) of the patients.

In the present study reticulate type of lesion were seen over buccal mucous membrane in 6 patients, over the lips in 5 patients and over the tongue in 2 patients. Erosive lesions were seen over the lips in 2 patients and over buccal mucous membrane in 2 patients. Papular lesions over the lips were seen in 2 patients and on the buccal mucous membrane in 1 patient. 


\begin{tabular}{|c|c|c|c|c|c|}
\hline $\begin{array}{c}\text { Type of } \\
\text { Lesions }\end{array}$ & Lips & Buccal & Tongue & Gums & Palate \\
\hline Reticulate & 5 & 6 & 2 & - & - \\
\hline Papular & 2 & 1 & - & - & - \\
\hline Atrophic & - & - & - & - & - \\
\hline Erosive & 2 & 2 & - & - & - \\
\hline Annular & - & - & - & - & - \\
\hline Plaque & - & - & - & - & - \\
\hline \multicolumn{7}{|c|}{ Table 9 }
\end{tabular}

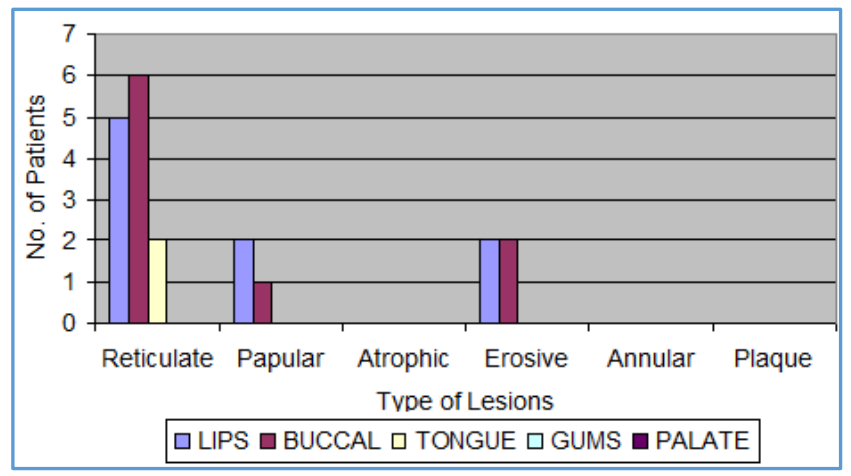

Figure 9

Koebner phenomenon was seen in $68 \%$ of the patients indicating an active disease in them.

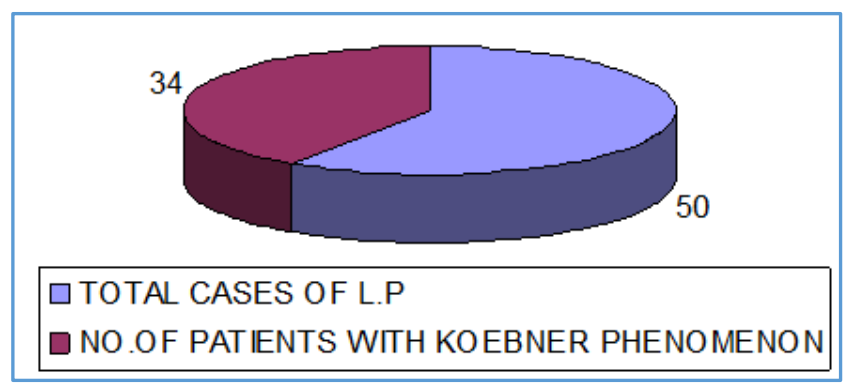

Figure 10

\begin{tabular}{|c|c|c|}
\hline Type of Involvement & $\begin{array}{c}\text { Finger } \\
\text { Nails }\end{array}$ & $\begin{array}{c}\text { Toe } \\
\text { Nails }\end{array}$ \\
\hline Longitudinal ridging & 6 & - \\
\hline Thinning & 3 & 2 \\
\hline Thinning \& longitudinal ridging & 2 & 1 \\
\hline Pitting & 2 & - \\
\hline $\begin{array}{c}\text { Thinning, pitting and longitudinal } \\
\text { ridging }\end{array}$ & 1 & - \\
\hline $\begin{array}{c}\text { Thinning, longitudinal ridging \& } \\
\text { onycholysis }\end{array}$ & 1 & - \\
\hline Total Table 10 & $\mathbf{1 5}$ & $\mathbf{3}$ \\
\hline \multicolumn{2}{|c}{} \\
\hline
\end{tabular}

\begin{tabular}{|c|c|c|}
\hline H/P Findings & $\begin{array}{c}\text { No. of } \\
\text { Cases }\end{array}$ & Percentage \\
\hline Hyperkeratosis & 49 & $98 \%$ \\
\hline Atrophy & 2 & $4 \%$ \\
\hline Parakeratosis & 2 & $4 \%$ \\
\hline Hypergranulosis & 43 & $86 \%$ \\
\hline Acanthosis & 44 & $88 \%$ \\
\hline Hyperplasia & 2 & $8 \%$ \\
\hline
\end{tabular}

\begin{tabular}{|c|c|c|}
\hline Saw toothing of rete ridges & 28 & $56 \%$ \\
\hline $\begin{array}{l}\text { Liquefactive degeneration of } \\
\text { basal cell }\end{array}$ & 34 & $68 \%$ \\
\hline Max Joseph space & 2 & $4 \%$ \\
\hline Colloid bodies & 2 & $4 \%$ \\
\hline $\begin{array}{r}\text { Table 11(a). H } \\
\text { Cutaneous L. }\end{array}$ & & \\
\hline
\end{tabular}

In the present study, hyperkeratosis was the commonest $(49,98 \%)$ finding in the epidermis followed by acanthosis $(44$, $88 \%)$ and hypergranulosis $(43,86 \%)$ respectively. Liquefactive degeneration of basal cells was seen in 34 (68\%) cases. In addition, exocytosis of lymphocytes and vacuolisation of stratum malpighii was seen in one case respectively, whereas focal spongiosis was present in 2 biopsies.

\begin{tabular}{|c|c|c|}
\hline H/P Findings & $\begin{array}{c}\text { No. of } \\
\text { Cases }\end{array}$ & Percentage \\
\hline Band-like infiltration & 46 & $92 \%$ \\
\hline Lymphocytes & 49 & $98 \%$ \\
\hline Histiocytes & 17 & $34 \%$ \\
\hline Plasma cells & 1 & $2 \%$ \\
\hline Melanophages & 15 & $30 \%$ \\
\hline Polymorphs & - & - \\
\hline Giant cells & - & - \\
\hline Melanin incontinence & 16 & $32 \%$ \\
\hline Perifollicular infiltrate & 3 & $6 \%$ \\
\hline $\begin{array}{c}\text { Perivascular lymphocytic } \\
\text { infiltrate }\end{array}$ & 2 & $4 \%$ \\
\hline Dysplasia of papillary dermis & 2 & $4 \%$ \\
\hline Table 11(b). Histopathology of Cutaneous L.P B: Dermis
\end{tabular}

In the dermis lymphocytic infiltration was the commonest $(49,98 \%)$ cell infiltration seen. Band-like infiltration pattern was seen in $46(92 \%)$ biopsies, whereas band-like lymphocytic infiltration was present in only 4 cases. Melanin incontinence was observed in $16(32 \%)$ patients and perivascular lymphocytic infiltrate in $2(4 \%)$ patients.

\begin{tabular}{|c|c|c|}
\hline H/P Findings & $\begin{array}{c}\text { No. of } \\
\text { Cases }\end{array}$ & Percentage \\
\hline Hyperkeratosis & 2 & $40 \%$ \\
\hline Parakeratosis & 4 & $80 \%$ \\
\hline Hypergranulosis & 2 & $40 \%$ \\
\hline Acanthosis & 2 & $40 \%$ \\
\hline $\begin{array}{c}\text { Saw tooth elongation of rete } \\
\text { ridges }\end{array}$ & 4 & $80 \%$ \\
\hline Basal cell degeneration & 5 & $100 \%$ \\
\hline Max Joseph space & 1 & $20 \%$ \\
\hline Colloid bodies & - & - \\
\hline Band-like infiltrate & 6 & $60 \%$ \\
\hline Lymphocytes & 5 & $100 \%$ \\
\hline Table 11(c). Histopathology of Oral L.P \\
\hline \multicolumn{2}{|c|}{} \\
\hline \multicolumn{2}{|c|}{} \\
\hline
\end{tabular}

In the present study out of 10 , biopsies were done in 5 cases, basal cell degeneration and lymphocytic infiltration were present in all the cases. Epidermal finding of parakeratosis was seen in $80 \%$ (4) of cases. 


\begin{tabular}{|c|c|c|c|}
\hline Skin Diseases & $\begin{array}{c}\text { No. of } \\
\text { Cases }\end{array}$ & $\begin{array}{c}\text { Other } \\
\text { Diseases }\end{array}$ & $\begin{array}{c}\text { No. of } \\
\text { Cases }\end{array}$ \\
\hline P. versicolor & 2 & Tonsillitis & 1 \\
\hline Moniliasis & 2 & Hypertension & 1 \\
\hline Scabies & 1 & Varicose veins & 1 \\
\hline Phrynoderma & 1 & $\begin{array}{c}\text { Thyroid } \\
\text { disorder }\end{array}$ & 1 \\
\hline $\begin{array}{c}\text { Alopecia } \\
\text { areata }\end{array}$ & 1 & Tuberculosis & 1 \\
\hline \multicolumn{2}{|c|}{ Table 12. Associated Conditions } \\
\hline
\end{tabular}

In our study patients, P. versicolor and moniliasis were seen as associated conditions in two cases respectively. Varicosity was noted in one case of hypertrophic lichen planus. Autoimmune conditions like alopecia areata and hypothyroidism was present in one patient respectively. Other non-cutaneous associated conditions like tonsillitis and hypertension was present in one patient of lichen planus respectively.

\section{DISCUSSION}

In the study of Sehgal and Rege, $46 \%$ of the patients belonged to the age group 21 - 40 years and $13 \%$ of them belonged to the age group up to 19 years. Boyd and Neldner ${ }^{2,1}$ observed that LP most commonly affects middle-aged adults with paediatric patients comprising of only $2 \%-3 \%$ of the patients. Kacchawa et al 3,4 in their study of 375 cases found $47 \%$ of the patients belonging to the age group of 20 - 39 years, $29 \%$ to 40 years and above, whereas only $18 \%$ of the patients belonged to the age group below 19 years. Arndt ${ }^{5}$ observed that twothirds of the patients belonged to the age group of $30-60$ years. Thus, the age incidence observed in the present study is similar to observations made in many studies as mentioned above.

In the present study, females constituted $58 \%$ of the patients and males $42 \%$ of the cases with a male ratio of $1.3: 1$. Boyd and Neldner ${ }^{2}$ observed that LP affects women preferentially and oral LP constituted in $63 \%$ - 67\% in women and cutaneous LP in $55 \%-65 \%$ of women. In the study of Sehgal and Rege, $652.4 \%$ were females and $47.6 \%$ males. The higher incidence among housewives is due to the fact that females constituted to more number of cases when compared to men. This probably reflects the cosmetic awareness among the females. Among labourers who constituted another major affected group, had more number of cases of actinic variety. This could be attributed to the fact that they are more exposed to sunlight because of the occupation. Similar observation were also made by Kacchawa et al. ${ }^{3}$

In the study of Sehgal and Rege $77 \%$ of the patients with mucous membrane lesions had habits like eating pan, betel nut, spicy food and alcohol, whereas among the patients who had only skin lesions these habits were seen in $43.4 \%$ of patients. In the majority of the Indian studies, it is observed that there is an increased risk of oral LP in those who smoke or chew tobacco. ${ }^{6}$ Compared to other studies the incidence of involvement of mucous membrane was comparatively less in the present study. This could be due to the fact that though there were tobacco chewers, many were casual than chronic.

Abdel-Hamid, Abdel-Aziz ${ }^{7}$ found papular variety of lichen planus in $33.33 \%$ of their cases and linear variety in less than $4 \%$. Gautam, Sharma found classical LP in 64.32 of their study patients, whereas Sehgal and Rege found this variety in $75.2 \%$ of their cases. Sehgal and Rege found hypertrophic LP in 15.5\% of the patients, out of which $3 / 4$ of the patients had lesions over the lower extremities. Silverstein et al found linear LP more commonly in children. The incidence of actinic LP is highly variable and depends upon the climatic factors and type of work. ${ }^{8}$ Dilaimy ${ }^{9}$ observed that actinic LP is a more common disorder in Middle East, East Africa and India.

In the present study, involvement of the oral mucous membrane was seen in 20 patients. In some patients, multiple sites were involved. Involvement of the lips and buccal mucosa were seen in 9 patients each respectively and tongue in 2 patients. None of the patients had involvement of the gums and palate. Reticulate type of lesions were the commonest pattern seen over buccal mucosa in 6 , over lips in 5 and on the tongue in 2 patients. Erosive lesions were seen over the lips and buccal mucosa in 2 patients each, whereas papular lesions were seen in 2 patients on the lips and in 1 patient over the buccal mucosa. Sehgal and Rege 10 in the study of 147 cases of LP found MM lesions in 48 patients, out of which $30(62.5 \%)$ had both skin and MM lesions and 18 had only MM lesions and $77.1 \%$ of the patients who had oral lesions had habits like eating pan, betelnut, spicy food, alcohol, etc. The location of the lesions was over the cheeks in $89.6 \%$, lips in $12.5 \%$ of the patients, tongue in $6.2 \%$ of the patients, palate in $4.2 \%$ of the patients and genitalia in $2.1 \%$ of patients. Greyish white dots, lines or patches were seen in $89.6 \%$ of the patients and erosions or ulcerations in $22.9 \%$ of the patients.

In the present study, Koebner phenomenon was observed in 34 patients $(68 \%)$. It was seen more over the areas prone for trauma and also areas accessible for scratching. Boyd and Neldner $^{2}$ found Koebner phenomenon as a common occurrence in LP developing in areas previously subjected to trauma of some type. Boyd and Neldner has quoted Koebner phenomenon occurring most frequently when the disease is unstable or in an acute stage of flaring. Black observed linear lesions often appearing along scratch marks. In the present study Koebner phenomenon was observed as a common finding, more over areas prone for trauma and areas accessible to scratching as observed in majority of the studies.

Fine Arndt observed nail changes in $6-10 \%$ of the patients which included longitudinal ridging, roughening, thinning, pitting, brownish discoloration, spooning, pterygium, subungual hyperkeratosis and loss of nails as the changes occurring in the order of frequency. 5,11,12 Altman, Perry, ${ }^{13}$ Scott and $\mathrm{Scott}^{14}$ reported nail changes occurring in 1 - 16\% of the patients, whereas Scott and $\operatorname{Scott}^{14}$ reported longitudinal ridging, grooving, splitting, striations, anonychia, subungual hyperkeratosis and thinning. Kacchawa et al, ${ }^{3}$ Abdel-Hamid and Abdel-Aziz ${ }^{7}$ reported nail changes in $6.4 \%$ and $7 \%$ of their patients of LP respectively with thinning, pterygium and complete destruction as the findings. Thus, in the present study the incidence of nail changes is comparatively high. This could be attributed to the fact that there were very few children in the study group and more number of patients were labourers and housewives who are prone for trauma which is one of the precipitating factor or the nail changes in some patients may be coincidental.

The small sample size and less number of biopsies taken were the limitations of the study. Many studies on epidemioclinical and histopathological lichen planus have been done before from different areas of the country, as there were no studies from Pune, Maharashtra. This study was undertaken in our tertiary care hospital. 


\section{REFERENCES}

1. Lichen planus-a clinico-histopathological. I J D V L 2008;66(4):193-5.

2. Boyd AS, Neldner KH. Lichen planus. J Am Acad Dermatol 1991;25(4):593-619.

3. Kachhawa D, Kachhawa V, Kalla G, et al. A clinico aetiological profile of 375 cases of lichen planus. Ind J Dermatol Venereol Leprol 1995;61(5):276-9.

4. Singh OP. Lichen planus in India. An appriaisal of 441 cases. International Journal of Dermatology 2008;15(10): 750-6.

5. Arndt KA. Lichen planus. Chapter 86, In: Text book of Dermatology in General medicine. Fitz Patrick TB. (edr.) New York, McGraw Hill, 1993:pp 2979.

6. Brody I. Electron microscopic demonstration of bacteria in the skin of patients with lichen ruber planus. Nature 1965;207(992):96-8.
7. Hamid A, Aziz AM. Lichen planus: histopathological study of 57 cases. Ind J Dermatol 1970;36(2):85-92.

8. Bouassida $\mathrm{S}$, Boudaya $\mathrm{S}$, Turki $\mathrm{H}$, et al. Actinic lichen planus: 32 cases. Ann Dermatol Venerol 1998;125(67):408-13.

9. Graells J, Notario J, Badia F. Lichen planus in monozygotic twins. Clin Exp Dermatol 1998;23(6):299.

10. Sehgal VN, Rege VL. Lichen planus: an appraisal of 147 cases. Indian J Dermatol and Venereol 1974;40(3):104-7.

11. Samman PS. The naires in lichen planus. Br J Dermatol 1961;73:288-92.

12. Sharma R, Maheshwari V. Childhood lichen planus: a report of 50 cases. Peditr Dermatol 1999;16(5):345-8.

13. Altman J, Perry HO. The variations and course of lichen planus. Arch Dermatol 1961;84:179-91.

14. Scott MJ. Ungula lichen planus. Arch Dermatol 1979;115:1197-9. 